\title{
БІОХІМІЧНІ ПОКАЗНИКИ КРОВІ КОТІВ ПРИ ХРОНІЧНІЙ НИРКОВІЙ НЕДОСТАТНОСТІ
}

\author{
С. Яцина, Т. Супрович
}

Подільський державний аграрно-технічний університет

Представлено результати біохімічного дослідження крові котів з хронічною нирковою недостатністю у порівнянні із здоровими тваринами. Встановлено взаємозв'язок між основними симптомами хвороби і біохімічними змінами в крові тварин. У хворих котів рівень креатиніну був вищий у 2,01 рази $(P<0,001)$ порівняно із здоровими тваринами; рівень сечовини був вищим у 1,8 рази $(P<0,001)$; показник фосфору був більше у 1,5 рази $(P<0,001)$.

Визначено, що активність ферменту аланінамінотрансферази у хворих котів становила

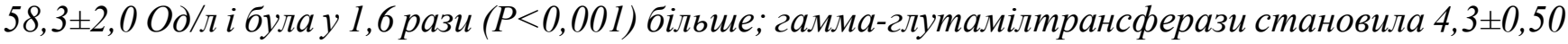
О д/л і була більше в 1,8 рази $(P<0,01)$ порівняно із здоровими котами.

Ключові слова: ниркова недостатність, кров, біохімічні показники, коти.

Постановка проблеми. Захворювання сечовидільної системи котів - одна із найчастіших причин звернення власників тварин у заклади ветеринарної медицини. У старших віком тварин найчастіше зустрічається ниркова недостатність, помітні клінічні ознаки якої проявляються на пізніх етапах хвороби (3-4 стадіï). Рання діагностика ускладнена відсутністю симптомів хвороби та іï клінічних проявів. Ниркова недостатність - патологічний стан, при якому нефронами втрачається їх функціональна здатність фільтрувати продукти життєдіяльності організму з крові [1]. Ниркову недостатність поділяють на дві форми: гостру та хронічну; при гострій формі процес відмирання нефронів зворотній та може бути вилікуваним; при хронічній формі у більшості випадків процес незворотній та погано піддається контролю та лікуванню. Хронічна ниркова недостатність поділяється на чотири стадії, в залежності від стадії спостерігаються різні клінічні прояви хвороби [2]. В зв'язку зі збільшенням популяції котів у містах та омолодженням хвороби постає питання ранньої діагностики захворювання. При плановому чи профілактичному обстеженні тварини важливо контролювати та діагностувати початок захворювань. Ниркова недостатність - це комплексне захворювання, яке уражає не тільки органи сечовиділення а й інші життєво важливі органи і системи [3].

Лабораторні і інструментальні методи дослідження допомагають встановити стадію захворювання та прогнозувати стан тварин і їхнє лікування. Одним із основних методів діагностики є біохімічне дослідження крові Визначення показників крові допомагає зрозуміти як працюють внутрішні органи, безпосередньо нирки, оцінити ступінь ураження та встановити стадію захворювання [4].

Аналіз останніх досліджень і публікацій. Аналіз представлених публікацій свідчить, що на сьогоднішній день діагностика та лікування хронічної недостатності нирок котів залишається однією з актуальних проблем ветеринарної медицини [5]. Як вказують автори у своїх публікаціях патологія нирок тісно пов'язана з порушеннями в роботі інших органів і систем, таких як серцевосудинна та органи травлення [6]. Незважаючи на те, що хронічна ниркова недостатність в кінцевому підсумку є прогресуючим розладом, рання діагностика та лікування можуть змінити швидкість прогресування та покращити якість та тривалість життя пацієнтів [7]. На ранніх етапах при гострому проявленні хвороби відмічається різке підвищення показників сечовини та креатиніну в 3-4 рази, при ренальній та постренальній стадії хвороби. Також збільшення рівню кальцію та фосфору в сироватці крові [8].

Хвороба може виникати як самостійне захворювання, так і як наслідок або комплекс інших хвороб. Такі патології, як кардіоміопатії, лівостороння серцева недостатність, закупорка уретри, урологічний синдром котів, порушення просвіту сечівників, отруєння, інтоксикації, викликають порушення кровотоку, накопичення великої кількості метаболітів, що в свою чергу ускладнює роботу нирок, перенавантаженні нефрони відмирають [9]. Виявлення хвороби на пізніх етапах ускладнює лікування. Прогноз для таких тварин від обережного до неблагопреємного. За допомогою планової діагностики біохімії крові, ультразвукового дослідження, лабораторного 
дослідження сечі, можливе виявлення ранніх проявів хвороби, та запобіганню ії ускладнень, а також виявлення порушень в роботі інших органів і систем.

Мета роботи: дослідити відмінності біохімічних показників крові котів 3 хронічною нирковою недостатністю та здорових котів.

Матеріали і методи дослідження. Біохімічне дослідження крові проведено на базі ветеринарних клінік «4 Лапи» (м. Кив), та «VitaeVet» (м. Кам’янець-Подільський). Діагноз на ниркову недостатність встановлювався комплексно, з урахуванням анамнезу, клінічних проявів, ультразвукового, рентгенологічного та лабораторного дослідження. Проби крові відбирали від котів різних порід, віку та статі. Попередньо було сформовано по мірі дослідження дві групи дослідних тварин: група 1 - здорові $(\mathrm{n}=5)$ та група 2 -хворі тварини $(\mathrm{n}=12)$. Забір крові проводився натще 3 латеральної підшкірної вени передньої кінцівки. Біохімічні показники сироватки крові досліджували за допомогою автоматичного аналізатора «STAT FAX 1904+» (США) з використанням реактивів фірми «СпайнЛаб» (Німеччина). Підготовку проб і визначення конкретних показників проводили згідно з інструкцією до приладу та реактивів.

У сироватці крові визначали: сечовину, креатинін, аланінамінотрансферазу (АлАт), аспартатамінотрансферазу (АсАт), гамма-глутамілтрансферазу (ГГТ), $\alpha$-амілазу, білірубіну, загальний білок, лужну фосфатазу, глюкозу, вміст кальцію, неорганічного фосфору та магнію.

Статистичну обробку результатів експериментальних досліджень проводили визначенням середнього арифметичного (М), його похибки (m) та рівня вірогідності (p) з використанням таблиці t-критеріїв Стьюдента.

Результати досліджень та їх обговорення. В період проведення дослідження у чотирьох тварин віком від 8 до 14 років, зі встановленим діагнозом хронічна ниркова недостатність спостерігалось поступове погіршення стану та смерть. У інших шести котів спостерігалась тимчасова втрата апетиту, блювання, діарея, шерсть збита та масна, апатія, летаргія, анорексія. При візуальному огляді ротової порожнини утворення язв на язиці та слизовій оболонці ротової порожнини, специфічний «кислий» запах.

У котів контрольної групи, у яких не було виявлено ознак хвороби, стан був задовільний, повноцінне поїдання корму, добовий діурез в межах фізіологічних норм, зовнішніх і внутрішніх патологічних відхилень за допомогою візуального, інструментального і лабораторного дослідження не виявлено.

За результатами отриманих даних встановлено, що показники біохімії крові у тварин двох дослідних груп суттєво відрізняються (табл. 1).

Взаємозалежність таких показників крові як сечовина і креатинін в різних клінічних ситуаціях використовується для визначення функції нирок. Креатинін екскретується нирками у незмінному вигляді шляхом клубочкової фільтрації, цей показник свідчить про швидкість клубочкової фільтрації. При порівнянні співвідношення концентрації креатиніну з показником питомої ваги сечі можна встановити стадію азотемії, преренальну - сеча буде концентрованою, ренальна - ізостенурія, постренальна - гіпостенурія [9]. Підвищення креатиніну (азотемії) у котів дослідної групи вказує на порушення роботи нирок, зниження швидкості фільтрації і як наслідок накопичення продуктів життедіяльності. У хворих тварин рівень креатиніну був вищий у 2,01 рази $(\mathrm{P}<0,001)$ порівняно з котами контрольної групи.

Сечовина - продукт азотистого обміну, який також використовують для оцінки швидкості клубочкової фільтрації (ШКФ). Її синтез залежить як від функціонування печінки так і від білкового балансу. Виведення сечовини нирками найбільш важливий фактор, що визначає рівень азоту сечовини крові. Сечовина вільно фільтрується в ниркових клубочках, 50-65\% профільтрованої сечовини пасивно реабсорбується з ниркових канальців $[10,17]$. Рівень сечовини у котів дослідної групи був вищим у 1,8 рази $(\mathrm{P}<0,001)$ порівняно 3 контрольною групою.

Аланінамінотрансфераза - це фермент, який присутній головним чином в клітинах печінки і нирок і в помітно менших кількостях в клітинах серця і м'язів. При ураженні клітин тканини печінки АЛаТ вивільняється в кровоток зазвичай ще до появи таких характерних симптомів як жовтяниця. У зв'язку з цим активність даного ферменту використовується в якості показника ушкоджень печінки і нирок $[12,17]$. Визначено, що активність ферменту АЛаТ у котів дослідної групи у 1,6 рази $(\mathrm{P}<0,001)$ більше ніж контрольної групи. 
Гамма-глутамілтрансфераза (ГГТП) являється ферментом, пов'язаним 3 клітинною мембраною, присутня в більшості типів клітин в основному в клітинах жовчних протоків та ниркових канальців. Підвищення значення показника в крові в сукупності з іншими показниками свідчить про захворювання гепатобіліарної системи. У хворих тварин рівень ГГТП був більше в 1,8 рази $(\mathrm{P}<0,01)$ порівняно із здоровими котами.

Аспартатамінотрансфераза (АСТ) - фермент локалізується в цитозолі і мітохондріях багатьох типів клітин. АСТ в найбільш високих концентраціях локалізується в клітинах скелетної мускулатури, в меншій - в печінці і міокарді. Також локалізується в еритроцитах, тому рівень ферменту в сироватці крові може підвищуватися при внутрішньосудинних гемолітичних порушеннях. Аспартатамінотрансфераза присутня в епітеліальних клітинах нирок і тканинах головного мозку. Вивільнення ферменту із цього виду тканин призводить до появи іï в сечі $\mathrm{i}$ спинномозковій рідині. Високі значення свідчать про порушення в роботі нирок, пошкодженні клітин нирок і печінки, запальні процеси як гепатит, панкреатит, травми, цироз, паразитарні ураження, гіпоксія отруєння [17]. У хворих котів спостерігається підвищення цього показника $(57,4 \pm 1,26$ Од/л), що в сукупності 3 іншими показниками свідчить про запальні процеси як в нирках, так і в шлунково-кишковому тракті.

Таблиця 1. Біохімічні показники крові котів з хронічною нирковою недостатністю $(\mathrm{M} \pm \mathrm{m})$

\begin{tabular}{|l|c|c|c|c|}
\hline \multicolumn{1}{|c|}{ Показник } & Референтні & Одиниці виміру & Група I $\left(\mathrm{n}_{1}=5\right)$ & Група II $\left(\mathrm{n}_{2}=12\right)$ \\
\hline Креатинін & $35-133$ & (Мкмоль/л) & $87,5 \pm 12,19$ & $176,2 \pm 5,24 * *$ \\
\hline Сечовина & $2,0-8,9$ & (Ммоль/л) & $5,6 \pm 0,66$ & $10,01 \pm 0,21^{* *}$ \\
\hline АлАТ & $12-45$ & (Од/л) & $36,3 \pm 2,61$ & $58,3 \pm 2,0 * *$ \\
\hline АсАт & $2-40$ & (Од/л) & $27,5 \pm 2,20$ & $57,4 \pm 1,26 * *$ \\
\hline$a$-амілаза & $30-720$ & (Од/л) & $408,1 \pm 58,35$ & $920,3 \pm 58,01^{* *}$ \\
\hline ГГТ & $1-3$ & (Од/л) & $2,4 \pm 0,34$ & $4,3 \pm 0,50 *$ \\
\hline Білірубін & $0,0-12,0$ & Мкмоль/л & $5,47 \pm 1,11$ & $6,23 \pm 1,18$ \\
\hline Загальний білок & $55-77$ & (Г/л) & $64,54 \pm 2,02$ & $62,4 \pm 2,47$ \\
\hline Лужна фосфатаза & $64-306$ & (Од/л) & $197,55 \pm 20,72$ & $131,92 \pm 18,90$ \\
\hline Кальцій & $2,0-2,7$ & (Ммоль/л) & $2,5 \pm 0,11$ & $2,56 \pm 0,14$ \\
\hline Фосфор & $1,1-2,3$ & (Ммоль/л) & $1,81 \pm 0,14$ & $2,73 \pm 0,11 * *$ \\
\hline Глюкоза & $3,3-6,3$ & (Ммоль/л) & $4,74 \pm 0,28$ & $5,02 \pm 0,30$ \\
\hline Магній & $0,72-1,12$ & (Ммоль/л) & $0,935 \pm 0,08$ & $0,872 \pm 0,57$ \\
\hline
\end{tabular}

Примітка. * $-\mathrm{P}<0,01$, ** $\mathrm{P}<0,001-$ порівняно з показниками у контрольної групи

Фермент $a$-амілаза гідролізує крохмаль і глікоген, синтезується в підшлунковій залозі і в тканинах багатьох інших органів, із плазми виводиться нирками. Підвищення цього показника може спостерігатися при знижені швидкості клубочкової фільтрації, уражені підшлункової залози, обструкції сечовивідних шляхів, захворюваннях печінки та кишечника [16]. У наших дослідженнях у котів дослідної групи спостерігалося дещо підвищення цього показника $(920,3 \pm 58,01$ Од/л).

Білірубін є одним із основних показників роботи гепатобіліарної системи. Високі значення свідчать про швидке руйнування еритроцитів (гемоліз), гемолітичну хворобу, жовтяницю. Діагностичне значення при хронічній нирковій недостатності полягає у виявленні гемолізу еритроцитів, анемії та можливій інтоксикації продуктами розпаду. У котів обох груп спостерігалися значення цього показника у межах норми $\left(\mathrm{n}_{1}=5,47 \pm 1,11\right.$ Мкмоль/л, $\mathrm{n}_{2}=6,23 \pm 1,18$ Мкмоль/л).

Концентрація загального білка в крові залежить від вмісту альбуміну та глобулінів. В сиворотці вимірюваний білок включає альбумін і всі глобуліни за виключенням витрачених під час утворення тромбу. Використовується для вимірювання статусу гідратації, оцінки причини анемії, набряку чи асциту. При хронічній нирковій недостатності важлива оцінка по даному показнику втрати ваги, захворювання печінки, нирок і шлунково-кишкового тракту [13]. Значення 
цього показника у тварин обох груп були досить високими але у межах норми. Можна зробити припущення що з основним захворюванням нирковою недостатністю має місце запальний процес невідомого походження.

Лужна фосфатаза пов'язана 3 клітинною мембраною і не вивільняється в зовнішнє середовище подібно ферментам первинних гранул [14]. Встановлено що рівень лужної фосфатази у котів обох груп знаходиться в межах нормальних значень та становить 197,55 20,72 Од/л у котів першої групи та 131,92士18,90 Од/л у другої.

Оскільки глюкоза являється джерелом енергії майже усіх тканин організму, аналіз іiі концентрації - це одне із найважливіших лабораторних показників. Рівень глюкози регулюється великою кількістю гормонів, основним із яких являється інсулін. Інсулін знижує концентрацію глюкози в плазмі, стимулюючи іï надходження в міоцити і адипоцити. Одними із показань для дослідження глюкози в крові є судоми, слабкість, сплутана свідомість, летагрія, кома, сепсис, поліурія, полідипсія, підозра на захворювання печінки чи ендокринної системи. Оцінюються системи органів шлунково-кишкового тракту, ендокринної системи, обміну речовин та функції нирок і сечовидільної системи [3]. Цей показник у котів обох груп знаходився в межах норми.

Кальцій - важливий структурний компонент кісток, необхідний для таких процесів як згортання крові, нервово - м'язова збудливість, скорочення скелетних м'язів і робота серцевосудинної системи. За нашими дослідженнями у тварин обох груп даний показник був в межах норми. Підвищення кальцію (гіперкальціємія) в сиворотці крові в більшості випадків являється причиною ниркової недостатності.

Фосфор (фосфат-іон) широко поширений в усьому організмі. Рівень фосфору пов'язаний 3 взаємодією 3 кальцієм, вітаміном $\mathrm{D}$, регулюється нирками, кишечником $\mathrm{i}$ кістками. Гіперфосфатемія може виявлятися при усіх формах азотемії. Ї̈̈ зв'язок з метаболічним ураженням кісток (ниркова остеодистрофія) являється ознакою хронічного захворювання нирок [11]. У тварин дослідної групи цей показник був більше порівняно з котами контрольної групи у 1,5 рази $(\mathrm{P}<0,001)$.

Магній являється другим по поширеності внутрішньоклітинним катіоном після калію и виступає в ролі ключового ко-фактора сотень ферментативних реакцій, окрім того він бере участь в синтезі АТФ, транспорті іонів і формуванні трансмембранного електричного градієнту. Магній використовується для оцінки системи органів серцево - судинної системи, ендокринної системи і обміну речовин, шлунково-кишкового тракту, нервово - м'язової системи, функції нирок и сечовидільної системи. Високі значення свідчать про ниркову недостатність, постренальну обструкцію, гіпотиреоз, гіпофункцію кори наднирників. Низькі значення вказують ураження ниркових канальців, посилений діурез після обструкції, гіперкальціємію, гіпокаліємію, зниження рівня фосфатів [15]. В наших дослідженнях концентрація магнію у котів обох дослідних груп була в межах норми.

Висновки і перспективи. Встановлено взаємозв'язок між основними симптомами хвороби і біохімічними показниками в крові котів при хронічній нирковій недостатності. У хворих і здорових тварин достовірно відрізняються показники крові, такі як сечовина, креатинін, кальцій, фосфор, аланінамінотрансфераза, аспартатамінотрансфераза, гамма-глутамілтрансферазу та $a$ амілаза.

Отже, при плановому та профілактичному дослідженні біохімії крові є можливість виявити ранні зміни в показниках й можливо запобігти виникненню і розвитку основного захворювання ниркової недостатності. Популяризація профілактичних обстежень у тварин допоможе виявляти дану патологію на ранніх етапах та успішно ії лікувати.

В подальшому планується проведення рентгенографії, ультразвукове дослідження, клінічне та біохімічне дослідження сечі у кішок з представленою патологією.

\section{Список використаних джерел}

1. Эллиот Дж., Гроера Г. Нефрология и урология собак и кошек. 2014. Москва, Аквариум Принт, 352 с.

2. Чандлер Э.А., Гаскелл К.Дж., Гаскелл Р.М. Болезни кошек. 2011. Москва. Аквариум Принт, 688 с. 
3. Морозенко Д. В. Хронічна ниркова недостатність домашніх котів (патогенез, діагностика і лікування) : автореф. дис... канд. вет. наук : 16.00.01. Біла Церква, 2008. 22 с.

4. Локес П.І., Кравченко С.О. Біохімічні показники крові та функціонального стану нирок кішок за полікістозу, ускладненого пієлонефритом. Вісник Білоиерків. держ. аграр. ун-ту : $3 б$. наук. праць. Біла Церква. 2008. Вип. 56. С. 110-112.

5. Борисевич Б.В., Свириденко В., Гуніч В.В. Гістологічна діагностика хронічної ниркової недостатності в котів. Науковий вісник ЛНУВМБТ імені С.3. Гжицького, 2016, т.18, № 3 (70).

6. Канівець Н.С., Діагностика хронічної ниркової недостатності у котів. науково-практична конференція професорсько-викладацького складу 22-23 квітня 2020 р. Полтава. С. 361-362.

7. O'Neill, D. G., Elliott, J., Church, D. B., McGreevy, P. D., Thomson, P. C., \& Brodbelt, D. C. (2013). Chronic Kidney Disease in Dogs in UK Veterinary Practices: Prevalence, Risk Factors, and Survival. Journal of Veterinary Internal Medicine, 27, 814-821.

8. Suslova, N.I., Shulzhenko, N.M., Semyonov, O.V., Shkvaria, M.M., Panasenko, E.A., Holubyev, O.V., Chudinova, E.A. (2018). Diagnosis and treatment characteristics of acute renal failure in dogs. Science and Technology Bulletin of SRC for Biosafety and Environmental Control of AIC, 6(2), 72-77. (in Ukrainian)

9. Горальський Л.П., Хомич В.Т., Кононський О.І. Основи гістологічної техніки і морфофункціональні методи дослідження у нормі та при патології. Житомир: Полісся, 2015. 288 c.

10. Борисевич Б.В., Гуніч В.В., Юшкова О.С. Клініко-морфологічні особливості ниркової недостатності у котів. Аграрний вісник Причорномор'я. Ветеринарні науки. 2014. Вип. 72. С. 3-7.

11. Лисенко А. Вплив фітодобавок «Кардіофіл» і «Фітохол» на біохімічні показники крові котів за умов ізоляційного стресу. Аграрний вісник Причорномор'я. 2020. Вип. 96. С. 34-43.

12. Маи Отс, Галина Земцовская, Нарушение фосфорно-кальциевого обмена у больных хронической почечной недостаточностью. Нефрология и диализ. 2002. Вып. 4. С. 182-185.

13. Тимошенко О.П., Снопенко О.С., Папєта Г.А., Коренєв М.І., Кравченко Н.О., Попова Х. А., Морфо-біохімічні характеристики поліморбідної патології печінки та нирок свійських котів та собак. Ветеринарія, технології тваринництва та природокористування. № 4. 2019. С. 148157.

14. Влізло В.В., Слівінська Л. Г., Максимович І.А. Лабораторна діагностика у ветеринарній медицині: довідник, 2-ге вид. Львів: Афіша, 2014. 152 с.

15. Барышев, Д.Ю., Шашанов И.Р., Пахмутов И.А., Чвала А. Морфофункциональные и биохимические показатели крови и мочи у кошек в норме и при комплексном лечении мочекаменной болезни. Ветеринарная практика. 2005. № 1 (28). С 19-23.

16. Ермоленко, В. М. Хроническая почечная недостаточность. Нефрология: руководство для врачей / под ред. И. Е. Тареевой. Москва, 2000. Гл. 39. С. 596-657.

17. Ваден Ш., Нолл Д., Смит Ф., Тиллей Л. Полное руководство по лабораторным и инструментальным исследованиям у собак и кошек. Пер. с англ. яз. Москва : Аквариум Принт, 2013. $1120 \mathrm{c}$.

\title{
БИОХИМИЧЕСКИЕ ПОКАЗАТЕЛИ КРОВИ КОШЕК ПРИ ХРОНИЧЕСКОЙ ПОЧЕЧНОЙ НЕДОСТАТОЧНОСТИ
}

\author{
С. Яцына, Т. Супрович
}

Представлень результать биохимического исследования крови кошек с хронической почечной недостаточностью по сравнению со здоровыми животными. Установлена взаимосвязь между основными симптомами болезни и биохимическими изменениями в крови животных. У больных котов уровень креатинина был выше в 2,01 раза $(P<0,001)$ по сравнению со здоровыми животными; уровень мочевины был выме в 1,8 раза $(P<0,001)$ показатель фосфора был больше в 1,5 раза $(P<0,001)$.

Определено, что активность фермента АлАТ у больных кошек составила 58,3 \pm 2,0 Ед / л и была в 1,6 раза $(P<0,001)$ больше; гамма-глутамилтрансферазы составляла 4,3 \pm 0,50 В д/л и была больше в 1,8 раза $(P<0,01)$ по сравнению со здоровыми кошками.

Ключевые слова: почечная недостаточность, кровь, биохимические показатели, кочки. 


\section{BIOCHEMICAL INDICATORS OF CATS' BLOOD IN CASE OF CHRONIC RENAL FAILURE}

S. Yatsyna, T. Suprovych

The results of biochemical examination of the blood taken from cats with chronic renal failure in comparison with healthy animals are presented. The relation between the main symptoms of the disease and biochemical changes in the blood of animals has been established. In sick cats, creatinine levels were 2.01 times $(P<0.001)$ higher than in healthy animals; urea level was 1.8 times higher $(P<0.001)$; phosphorus index was 1.5 times higher $(P<0.001)$.

It was determined that the activity of the alanine aminotransferase enzyme in sick cats was $58.3 \pm 2.0$ U/l and 1.6 times $(P<0.001)$ higher; gamma-glutamyltransferase was $4.3 \pm 0.50 \mathrm{U} / \mathrm{l}$ and 1.8 times higher $(P<0.01)$ compared to healthy cats.

Keywords: renal failure, blood, biochemical parameters, cats. 